\title{
Violetta Rutkowska*
}

Uniwersytet Szczeciński

\section{ZARZĄDZANIE WARTOŚCIĄ KLIENTA SAMORZĄDU TERYTORIALNEGO}

\begin{abstract}
Streszczenie
Badania demograficzne informują, iż społeczeństwo europejskie cechują niski wskaźnik dzietności i wydłużająca się linia życia osób po 60. roku życia. W związku z tym władze rządowe i samorządowe zaczynają wprowadzać specjalne programy, które są skierowane do określonej grupy społecznej i mają na celu poprawę jakości życia. Problematyka dotyczy seniorów, czyli osób w wieku $60+$, oraz rodzin wielodzietnych (3+). Zadanie do wykonania jest obarczone dużym stopniem trudności. Z jednej strony samorząd terytorialny musi umocnić swoją pozycję przez poprawę jakości świadczonych usług w sytuacji, gdy w świadomości mieszkańców urząd nie ma pozytywnego wizerunku. Natomiast z drugiej strony współczesny klient jest już bardziej wymagający niż w latach ubiegłych. Wzrost świadomości klienckiej mieszkańców wymaga zastosowania skonkretyzowanej polityki lokalnej ukierunkowanej na rezultaty. Pogodzenie tych dwóch opcji jest trudne, lecz możliwe do zrealizowania. Istnieją projekty stworzone przez władze administracji rządowej mające na celu wprowadzenie standardów obsługi klienta w placówkach administracji publicznej. Proces został już zapoczątkowany. Trwają prace nad tworzeniem nowych wzorców na podstawie badań przeprowadzonych w gminach, w których zainicjowano wdrażanie
\end{abstract}

*Adres e-mail: violettarutkowska@o2.pl lub violetta.rutkowska@um.gorzow.pl. 
standardów obsługi klienta. To duży postęp w instytucjach administracji publicznej, który jest nieunikniony i będzie ewoluował, jeśli administracja publiczna ma stać się nowoczesna i otwarta na potrzeby klienta.

Słowa kluczowe: klient/interesant, zarządzanie w administracji publicznej, transformacje w urzędach

\section{Wprowadzenie}

Fundamentem każdego państwa jest naród i to on pełni najistotniejszą rolę. Natomiast ważną grupę społeczną w obrębie państwa stanowi rodzina. W związku z tym wszelkie działania rządu i samorządów muszą być ukierunkowane na stworzenie jej warunków godnego życia i rozwoju aż do później starości. Na powyższych szczeblach ujawnia się wzajemna korelacja między polityką prorodzinną i polityką senioralną. Priorytetem okazuje się zabezpieczenie odpowiednich warunków ekonomicznych i bytowych, na przykład: wprowadzenie ulg podatkowych, dodatków płacowych, systemu doraźnej pomocy rodzinie i seniorom, zagwarantowanie mieszkań dla mniej zamożnych rodzin czy stworzenie godnych warunków mieszkaniowych dla seniorów z problemami zdrowotnymi, wprowadzanie programów samorządowych lub rządowych, dzięki którym starsi ludzie i duże rodziny mogą dokonywać zakupów i korzystać z usług po preferencyjnych cenach.

Władze publiczne, kierując się troską o dobro publiczne swoich obywateli, starają się zmodyfikować wszelkie swoje działania, aby ułatwić mieszkańcom funkcjonowanie w regionie. Tymczasem współczesność wymusza na organach samorządowych i rządowych dodatkowo określone zachowania w stosunku do pewnych grup społecznych, które są szczególnie wrażliwe i wymagają opieki państwa. Dobrym rozwiązaniem jest wprowadzenie polityki międzypokoleniowej, która stanowi wyraz tej relacji i zarazem odpowiedź na potrzeby społeczeństwa, ponieważ nie można mówić o „zdrowym” starzeniu się społeczeństwa bez dostrzegania potrzeb ludzi młodych i aktywnych na rynku pracy. Szczególnie istotne jest współuczestnictwo władz rządowych, samorządowych, instytucji pozarządowych, gdyż przy dobrej współpracy wszystkich zainteresowanych można zbudować kompleksową politykę społeczną ze szczególnym uwzględnieniem senioralnej i prorodzinnej. Systematyczne przygotowywanie obywateli do zmian i wzmacnianie już istniejącego potencjału w określonych grupach społecznych, między innymi w ich relacjach, może 
zagwarantować właściwą politykę społeczno-ekonomiczną dla gorzowian. Zgromadzony potencjał w mieszkańcach jest niejako spoiwem lokalnej społeczności (seniorów i rodzin wielodzietnych), który można wykorzystać na potrzeby regionu. Stanowi również fundament koncepcji rozwoju inicjatyw samorządowców, które można włączyć do stałej oferty miejskiej lub zglobalizować, tworząc w pionie rządowym ofertę dla obywateli.

\section{Obsługa klienta samorządowego}

Funkcjonowanie administracji samorządu terytorialnego w globalizującej się gospodarce światowej sprawia, że instytucje samorządu terytorialnego zauważają potrzebę racjonalizacji w gminie. Szczególnie ważnym aspektem poprawy kondycji funkcjonowania samorządów gminnych jest ulepszanie jakości świadczonych usług oraz polityki lokalnej mieszkańców gminy. Zaczyna dostrzegać się klienta/interesanta w urzędzie, zmieniając sposób działania. Aspekt został zauważony przez władze rządowe i stworzono projekt „Klient w centrum uwagi administracji” (szerzej zob. Kancelaria Prezesa Rady Ministrów, 2012a). W publikacji Kancelarii Rady Ministrów czytamy: „Proces wdrażania standardów obsługi klienta w oparciu o zarządzanie satysfakcją klienta przeszedł praktyczną weryfikację w urzędach podczas realizacji projektu «Klient w centrum uwagi administracji» (Kancelaria Prezesa Rady Ministrów, 2012a, s. 7). Ponadto w celu poprawy jakości obsługi Ministerstwo Rodziny Pracy i Polityki Społecznej dofinansowuje projekty na rzecz usprawnienia administracji publicznej.

Wprowadzenie standardów obsługi klienta bezsprzecznie przyczynia się do wzrostu efektywności funkcjonowania administracji przez: uproszczenie procedur, skrócenie czasu oczekiwania na rozpatrzenie spraw, usprawnienie procesu stanowienia prawa lokalnego i wydawania aktów administracyjnych w tym zakresie, poprawę jakości tworzonej przez gminę strategii i polityki lokalnej, rozwój wiedzy i umiejętności urzędników, wzmacnianie kształtowanie postaw etycznych, informowanie społeczeństwa o swoich działaniach, jawność działań, badanie opinii publicznej mieszkańców na temat własnej działalności i realizowania zadań.

Obecnie zaczyna przywiązywać się uwagę do zbudowania relacji z klientem/interesantem wykraczających poza zachowania urzędników wyłącznie mechaniczne i nadmiernie służbowe. Wiadomo, że instytucje publiczne muszą działać zgodnie 
z procedurą i aktami normatywnymi, lecz sposób wykonania tej procedury można udoskonalić, czerpiąc z wzorców z zewnątrz. Osoba udająca się ze sprawą do urzędu oczekuje już innej formy obsługi: profesjonalnej, kompetentnej, uprzejmej i dążącej do zaspokojenia jego potrzeb, czyli satysfakcji z jakości otrzymanej w urzędzie obsługi. Celem projektu rządowego „Klient w centrum uwagi administracji” było „usprawnienie pracy urzędów administracji rządowej w oparciu o zarządzanie satysfakcją klienta, a w dalszej perspektywie projakościowa i prokliencka reorientacja systemów zarządzania w urzędach. Oczekiwanym rezultatem jest pozytywny wizerunek urzędów administracji rządowej w opinii obywatela" (Kancelaria Prezesa Rady Ministrów, 2012a, s. 7). Długoterminowe relacje zbudowane na satysfakcji to kluczowy punkt dobrego zarządzania wartością klienta. Satysfakcja z obsługi na wysokim poziomie jest zachętą do ponownego skorzystania z usług urzędu w przyszłości. Specjaliści zajmujący się analizą tego zagadnienia określają to w sposób następujący: „Zarządzanie satysfakcją klienta jest niezbędne dla instytucji publicznych po to, aby mogły przekonać się, czy robią właściwe rzeczy i czy wykonują te rzeczy we właściwy sposób” (Kancelaria Prezesa Rady Ministrów, 2008, s. 8; szerzej zob. Kancelaria Prezesa Rady Ministrów, 2008, passim).

Od wielu lat analitycy zajmują się badaniem stopnia zadowolenia klientów i tworzą określone standardy, aby wprowadzić usprawnienia i móc porównywać jakość funkcjonowania poszczególnych urzędów czy instytucji publicznych. Kluczowym elementem i ekspertem w tym zakresie jest urzędnik, który jako praktyk potrafi skutecznie wskazać kierunki satysfakcji klienta/interesanta. „Koncepcja zarządzania satysfakcją klienta dąży do większego zaangażowania klienta/obywatela w proces kształtowania usług poprzez badanie wykraczające poza poziom zadowolenia, a sięgające do głębiej ukrytych potrzeb i oczekiwań względem urzędów, urzędników i samej usługi. Obecnie klient staje się też ekspertem w zakresie zmian jakie należy wprowadzić w obsłudze i sposobie dostarczania usługi. Standardy obsługi klienta są odpowiedzią na potrzeby i oczekiwania mieszkańców" (Kancelaria Prezesa Rady Ministrów, 2012b, s. 9).

\section{Potrzeby klienta samorządu terytorialnego}

Podstawowym aktem normatywnym, na mocy którego funkcjonują organa administracji publicznej, jest Konstytucja RP, która w Rozdziale VII w sposób szczegóło- 
wy opisuje samorząd terytorialny (zob. Konstytucja, 1997). Zgodnie z nią podstawową jednostką samorządu terytorialnego jest gmina, która realizuje samodzielnie i na własną odpowiedzialność zadania własne wiążące się z zaspokojeniem potrzeb mieszkańców gminy oraz wykonuje zadania zlecone przez administrację rządową dla członków wspólnoty samorządowej, czyli mieszkańców. Źródłem finansowania samorządu terytorialnego są: dochody własne, subwencje na wykonywanie zadań własnych oraz dotacje celowe na zadania zlecone z budżetu państwa.

Gmina pozyskuje dodatkowe dochody we własnym zakresie, z podatków i opłat lokalnych oraz opłat za użytkowanie mienia komunalnego. Budżet gminy uchwalany jest przez Radę Miasta, która jest organem stanowiącym i kontrolnym. Na sesjach Rady Miasta podejmowane są uchwały w zakresie: podatków i opłat lokalnych, planu zagospodarowania przestrzennego oraz współpracy z innymi gminami. Władzę wykonawczą sprawuje prezydent miasta, któremu służą pomocą pracownicy urzędu na każdym etapie. Mają za zadanie na przykład reprezentowanie gminy na zewnątrz czy też dbanie o promocję gminy, dlatego istotny staje się fakt zabiegania o satysfakcję klienta urzędu. Jest to szalenie trudne, gdyż urząd ma do czynienia z ludźmi. Ważne są relacje z klientami/interesantami, wizerunek i reputacja. Człowiek natomiast jest jednostką nieprzewidywalną, emocjonalną, niemożliwą do opanowania i zamknięcia w sztywne reguły, aby od razu odnaleźć rozwiązanie na wszelkie problemy mieszkańców. Dlatego zarządzanie tym specyficznym systemem jest trudne i złożone, lecz możliwe do zrealizowania. Stosując analogię i porównując funkcjonowanie instytucji państwowej do prywatnej, zauważa się, że urząd napotyka na wiele ograniczeń, z którymi nie ma do czynienia firma prywatna. Jednak gmina, stosując metody i techniki zarządzania instytucji prywatnej, mimo wszystko może poprawić efektywność i skuteczność działania, a także swój wizerunek u klienta. Mieszkaniec gminy jest jej źródłem funkcjonowania. O jego potrzeby należy zadbać, aby był zadowolony i chętnie wracał w celu skorzystania z usług urzędu. Naukowcy twierdzą, iż znaczącą rolę u klienta odgrywają czynniki psychologiczne takie jak: potrzeby, emocje, wartości. Nic dziwnego, że specjaliści rządowi zaczynają wprowadzać nowe wytyczne i standardy dotyczące procedur obsługi klienta/interesanta, wzorując się na prywatnym biznesie. Jedynie zachowując się jak prywatni przedsiębiorcy, którzy dbają o swoich klientów, organy administracji publicznej mogą poprawić swój wizerunek, który zrywa z powszechnymi stereotypami i nadaje nowy wymiar urzędowi, jako otwartemu i przychylnemu 
mieszkańcom, ceniącemu sobie uwagi, zauważającemu problemy i starającemu się je rozwiązać w sposób optymalny. Rozwój mentalności klienckiej również wpływa na żądania i oczekiwania mieszkańców dotyczące nowych rozwiązań, reform, projektów, programów w celu poprawy zaufania społecznego, dlatego organy administracji publicznej starają się zapewnić:

- większy wybór możliwości w usłudze dodatkowej, między innymi dostarczenie do domu dokumentu tożsamości dla osoby niepełnosprawnej, możliwość zwykłego pełnomocnictwa do załatwienia spraw prostych,

- demokrację, polegającą na przykład na organizowaniu konsultacji społecznych na temat danego problemu i współdecydowanie co do wyboru przedsięwzięcia,

- przejrzystość - współpraca z mieszkańcami na etapie procesu świadczenia usług w urzędzie, na przykład szybki dostęp do informacji publicznej, możliwość obejrzenia monitoringu z obrad Sesji Rady.

W obecnych realiach tempo przekształceń wymusza na organach administracji państwowej wprowadzanie określonych zmian w funkcjonowaniu instytucji państwowych, gdyż istotny jest sposób postrzegania danej organizacji.

Powszechnie wiadomo, że na korzystny wizerunek organu samorządowego ma wpływ tworzenie prawa miejscowego. Właściwe akty normatywne dostosowane do potrzeb wspólnoty lokalnej powodują wzrost zaufania społecznego i zadowolenie mieszkańców z władz miasta. Dlatego tak ważne jest zidentyfikowanie i wyeksponowanie potrzeb mieszkańców danej gminy, aby precyzyjnie dopasować przepisy do oczekiwań obywateli.

Aktualnie zaczyna dostrzegać się, że to dzięki klientowi urząd funkcjonuje, a profesjonalne zachowanie urzędnika wpływa na korzystny wizerunek urzędu. Konkretyzując sytuację, można stwierdzić, że nawet profesjonalnie zrealizowana usługa urzędowa (zgodna z procedurami prawnymi i różnymi aktami wykonawczymi) przy jednoczesnym nieuprzejmym zachowaniu urzędnika kształtuje negatywny odbiór urzędu w oczach interesanta. Eksperci określają tę sytuację jako obraz opinii mieszkańców danej instytucji, a nie obraz rzeczywisty i szczegółowy. Doprecyzowując: jest to zlepek różnych informacji; tego, co widzimy i porównujemy z tym, co wiemy, a raczej z tym, co sobie wyobrażamy. Upraszając, wszystko to, co mieszkańcy myślą na temat urzędu. 


\section{Obsługa programu rządowego Karta Dużej Rodziny}

Rządowy program Karta Dużej Rodziny jest elementem polityki społecznej realizowanej przez państwo na rzecz rodzin wielodzietnych 3+ (MRPiPS, 2018). Posiadacze Karty Dużej Rodziny mogą korzystać z ulg i zniżek na terenie całej Polski, oferowanych przez podmioty uczestniczące w programie. Kartę może otrzymać rodzina składająca się z rodziców czy rodzica (w tym również zastępczych), posiadających na utrzymaniu troje i więcej dzieci do ukończenia przez nich 18. roku życia lub 25. roku życia w przypadku, gdy dziecko się uczy lub studiuje. W odniesieniu do dzieci, którym przyznano orzeczenie o umiarkowanym lub znacznym stopniu niepełnosprawności nie obowiązuje ograniczenie wieku stosownie do orzeczenia. Karta przysługuje również osobie prowadzącej rodzinny dom dziecka. Fakt posiadania reguluje Ustawa z dnia 5 grudnia 2014 r. o Karcie Dużej Rodziny (Ustawa, 2014) oraz Rozporządzenie Ministra Rodziny, Pracy i Polityki Społecznej z dnia 27 lipca 2017 r. w sprawie sposobu unieważnienia Karty Dużej Rodziny, wzorów graficznych oraz szczegółowego zakresu informacji, jakie mają być zawarte we wniosku o przyznanie Karty Dużej Rodziny (Rozporządzenie, 2017b), które niedawno zmieniono Rozporządzeniem zmieniającym Ministra Rodziny, Pracy i Polityki Społecznej z dnia 28 grudnia 2017 r. w sprawie sposobu unieważnienia Karty Dużej Rodziny, wzorów graficznych oraz szczegółowego zakresu informacji, jakie mają być zawarte we wniosku o przyznanie Karty Dużej Rodziny (Rozporządzenie, 2017a).

Finansowanie Ogólnopolskiej Karty Dużej Rodziny opiera się na dotacji celowej otrzymywanej z budżetu państwa na realizację zadania zleconego. W zależności od wstępnych założeń gminy przyznawane są środki gminie na dany rok. W przypadku niewykorzystania przyznanej kwoty $\mathrm{w}$ danym roku środki podlegają zwrotowi do budżetu państwa zgodnie z art. 168 Ustawy z dnia 13 października 2017 r. o finansach publicznych (Ustawa, 2017, art. 168).

Tabela 1 przedstawia finansowanie programu rządowego Ogólnopolska Karta Dużej Rodziny. Odnotowano znaczny przyrost finansowy z tytułu wpłat za wyrobienie duplikatów kart w stosunku do roku 2016 i wynosił on 174,99 zł. W roku 2017 na realizację zadania rządowego została przyznana dotacja celowa w wysokości 2 338,30 zł, jednak wypracowano przysługujące koszty w wysokości 1 956,40 zł. Wystąpiła nadwyżka finansowa w wysokości 381,90 zł, która podlegała zwrotowi do budżetu państwa. Podobny stan rzeczy zarejestrowano w roku 2016. Sytuacja 
może sugerować dwie możliwości: przy szacowaniu kosztów słabe zorientowanie na potrzeby rodzin co do posiadania Ogólnopolskiej Karty Dużej Rodziny lub zbyt małe zainteresowanie rodzin wielodzietnych uprawnionych do posiadania karty w stosunku do prognoz.

Tabela 1. Rozliczenie z dotacji celowej na realizację zadania

\begin{tabular}{|l|c|c|c|c|}
\hline \multicolumn{1}{|c|}{ Przedział czasowy } & $1.01-30.06 .2016$ & $1.07-31.12 .2016$ & $1.01-30.06 .2017$ & $1.07-31.12 .2017$ \\
\hline $\begin{array}{l}\text { dotacja celowa na realizację } \\
\text { zadania }\end{array}$ & $1176,10 \mathrm{zł}$ & $1118,90 \mathrm{zł}$ & $1157,76 \mathrm{zł}$ & $1180,54 \mathrm{zł}$ \\
\hline $\begin{array}{l}\text { przysługujące koszty na } \\
\text { realizację zadania }\end{array}$ & $1031,80 \mathrm{zł}$ & $1031,80 \mathrm{zł}$ & $938,00 \mathrm{zł}$ & $1018,40 \mathrm{zł}$ \\
\hline $\begin{array}{l}\text { zwrot kwot do budżetu } \\
\text { państwa przez gminę }\end{array}$ & $144,30 \mathrm{zł}$ & $87,00 \mathrm{zł}$ & $219,76 \mathrm{zł}$ & $162,14 \mathrm{zł}$ \\
\hline $\begin{array}{l}\text { dochody do budżetu } \\
\text { z tytułu duplikatów kart }\end{array}$ & $35,00 \mathrm{zł}$ & $43,75 \mathrm{zł}$ & $73,68 \mathrm{zł}$ & $101,31 \mathrm{zł}$ \\
\hline
\end{tabular}

Źródło: opracowanie własne na podstawie danych pierwotnych z Systemu Informatycznego Karty Dużej Rodziny (SI KDR).

Zestawienie powyższe ukazuje jednak, że zainteresowanie Ogólnopolską Kartą Dużej Rodziny jest znaczne, ponieważ rodziny wielodzietne mogą korzystać z ulg i zniżek na terenie całego kraju. Od początku funkcjonowania programu, czyli od połowy roku 2014, do 31.12.2017 roku wydano 5079 kart oraz złożono 1214 wniosków ${ }^{1}$.

Poniżej przedstawiono zainteresowanie Ogólnopolską Kartą Dużej Rodziny wśród mieszkańców Gorzowa Wielkopolskiego.

Z rysunku 1 wyłaniają się wnioski następującej treści: „...ilość rodzin ubiegających się o Kartę oscyluje na zbliżonym poziomie. Podobna relacja jest zachowana w przypadku przyznawania kart wnioskodawcom, którzy ubiegali się o nią po raz pierwszy. Parametry na razie nie wskazują diametralnej poprawy dzietności w rodzinach, jedynie ukazują wysycenie rynku rodzinami, które posiadały uprawnienia do ubiegania się o Kartę Dużej Rodziny i delikatną tendencję wzrostową dla rodzin, które obecnie wkraczają w uprawnienia do posiadania Karty Dużej Rodziny. Natomiast w roku 2017 znacząco odnotowano wzrost wydania kart rodzinom wielodziet-

1 Szerzej w Sprawozdaniu z realizacji programu Karta Dużej Rodziny - Uchwała Nr LII/598/2017 Rady Miasta Gorzowa Wielkopolskiego z dnia 27 września 2017 r. zmieniona Uchwałą Nr LVIII/725/2018 Rady Miasta Gorzowa Wielkopolskiego z dnia 31 stycznia 2018 r. za rok 2017. 
nym, które były już posiadaczami” (Rutkowska, 2018, s. 12). Ponadto odnotowano sytuacje, w których rodziny wielodzietne nie ubiegają się wcale o zwolnienie z uiszczenia opłaty z tytułu wyrobienia duplikatu kart, co może świadczyć o tym, że kwota jest idealnie dopasowana do zasobności budżetu domowego rodzin wielodzietnych i utrata karty nie stanowi problemu finansowego , którym przyznano orzeczenie

Rysunek 1. Obsługa Programu OKDR

\section{Zestawienie za okres: 01.01.2016-31.12.2017r. Obsługa Programu OKDR}

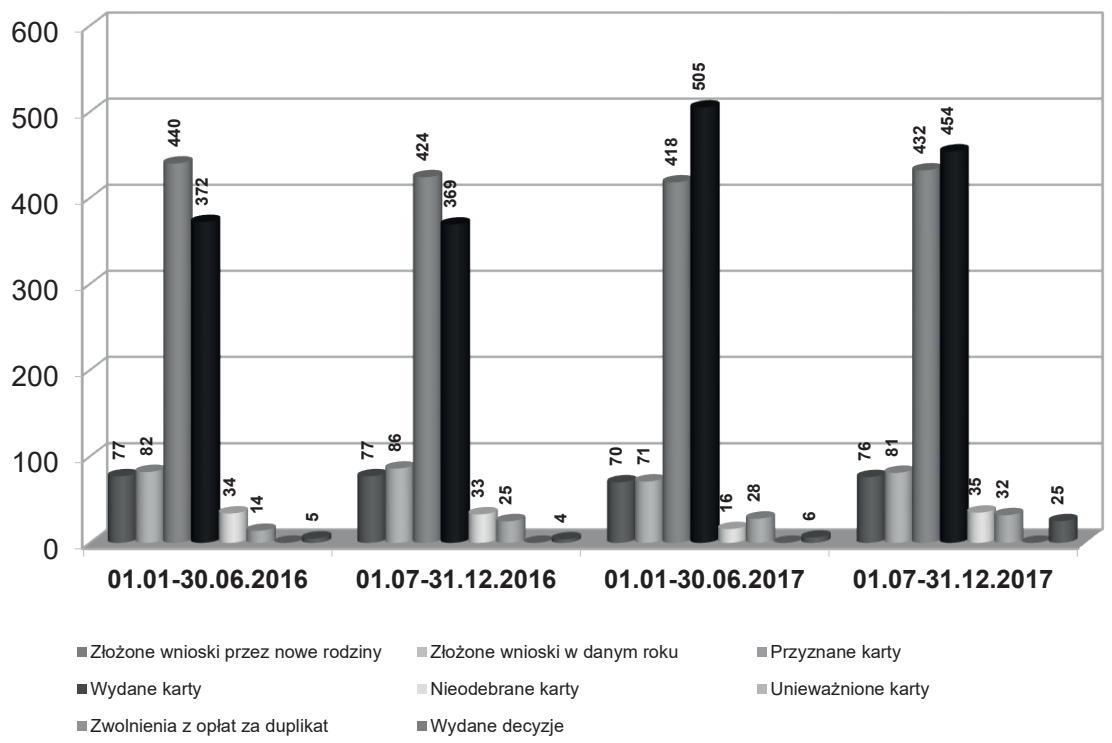

Źródło: opracowanie własne na podstawie danych z SI KDR.

\section{Lokalne programy samorządowe: Karta Seniora, Gorzowska Karta Dużej Rodziny}

Miasto Gorzów Wielkopolski staje się otwarte na przyszłość i stara się dbać o mieszkańców w każdym wieku. Widząc potrzeby osób starszych i rodzin wielodzietnych w różnych obszarach życia codziennego, postarało się uruchomić lokalne 
programy mające wesprzeć najbardziej potrzebujące grupy społeczne gorzowian: seniorów i duże rodziny.

Wprowadzenie na terenie Gorzowa Wielkopolskiego programów lokalnych: Gorzowskiej Karty Dużej Rodziny oraz Gorzowskiej Karty Seniora, przyczyniło się do wzrostu zaufania mieszkańców do władz miasta. Dwie grupy społeczne gorzowian borykające się z największymi trudnościami finansowymi otrzymują pomoc w postaci specjalnie dla nich kierowanych programów, dzięki którym mają możliwość korzystania z upustów i rabatów na określone produkty, usługi. Mieszkańcy z zainteresowaniem obserwowali wprowadzane zmiany, które zostały pozytywnie przez nich odebrane.

Należy pamiętać, iż kompleksowa obsługa wprowadzonych lokalnych programów jest sprawą kosztowną, gdyż cały ciężar prowadzenia i obsługi danego programu spoczywa na gminie realizującej wytyczne z uchwał Rady Miasta. Dodatkowo wpływy do budżetu gminy są zmniejszone, jeśli partnerami programów są miejskie instytucje, które oferują zniżki i ulgi. Jednak niewątpliwie jest to korzyść dla miasta, mająca wymiar społeczny, kształtujący pozytywny wizerunek urzędu, który troszczy się o swoich mieszkańców i stara się im pomóc. Sytuację finansową miasta można nieco odciążyć i poprawić dzięki skupieniu się nad pozyskiwaniem nowych partnerów do programów ze środowiska komercyjnego (biznesu), co zagwarantuje rzeczywisty zysk dla miasta bez uszczerbku finansowego dla gminy.

Miasto, zachęcając gorzowski biznes do udziału w lokalnych programach, daje możliwości przedsiębiorcom w postaci: kreowania własnego niepowtarzalnego wizerunku, marki wpływającej na jakość życia mieszkańca Gorzowa Wielkopolskiego, bezpłatnej bezterminowej reklamy w internecie oraz promocji działalności przez umieszczenie na stronie internetowej miasta logo firmy czy instytucji wraz z linkiem aktywnym do portalu firmy lub instytucji, bezpłatnego umieszczenia danych partnerów w Katalogach Ulg i Zniżek Programu Kart: Seniora i Dużej Rodziny, budowania długoterminowych relacji z klientami w każdej grupie wiekowej, prestiżu, regularnego ukazywania się aktualizacji o partnerze programu w bezpłatnych publikacjach miejskich, „Gorzowskich Wiadomościach Samorządowych”, na stronie internetowej miasta czy fanpage'u. 


\subsection{Gorzowska Karta Dużej Rodziny}

Karta Dużej Rodziny jest integralną częścią programu wspierania rodzin wielodzietnych w Gorzowie Wielkopolskim pod nazwą Gorzowska Karta Dużej Rodziny. Posiadacze karty mogą skorzystać z ulg i zniżek oferowanych przez podmioty uczestniczące w programie.

Na mocy Uchwały Nr LVIII/661/2013 Rady Miasta Gorzowa Wielkopolskiego z dnia 27 listopada 2013 r. w sprawie wprowadzenia na terenie Miasta Gorzowa Wlkp. Programu „Karta Dużej Rodziny” zostały złożone podwaliny pod funkcjonowanie programu, która została zmieniona Uchwałą Nr XIII/119/2015 Rady Miasta Gorzowa Wielkopolskiego z dnia 24 czerwca 2015 r. oraz Zarządzeniem $\mathrm{Nr}$ 345/I/2015 określającym szczegółowe warunki uczestnictwa w programie Prezydenta Miasta Gorzowa Wielkopolskiego z dnia 17 lipca 2015 r. w sprawie ustalenia logo Programu „Karta Dużej Rodziny” oraz Regulaminu przyznawania, wydawania i korzystania z „Karty Dużej Rodziny”. Natomiast 21 października 2017 r. wprowadzono Uchwałę nr LII/598/2017 Rady Miasta Gorzowa Wielkopolskiego z dnia 27 września 2017 r. w sprawie przyjęcia Programu „Gorzowska Karta Dużej Rodziny", którą zmieniono Uchwałą nr LVIII/725/2018 Rady Miasta Gorzowa Wielkopolskiego z dnia 31 stycznia $2018 \mathrm{r}$. Na mocy tego aktu normatywnego wprowadzono nowy wzór graficzny, zmieniono termin ważności karty oraz ujednolicono zapisy uchwały z zapisami Ustawy o Karcie Dużej Rodziny z dnia 5 grudnia 2014 r. Dalsze zmiany dotyczyły przeniesienia obsługi Karty Dużej Rodziny do budynku głównego Urzędu Miasta Gorzów Wielkopolski i od 2 listopada 2017 roku można było składać wnioski oraz odbierać karty w budynku głównym Urzędu Miasta w Sali Obsługi Klienta.

Program przede wszystkim ma za zadanie promować model rodziny wielodzietnej 3+ (w tym rodziny zastępcze) oraz jej pozytywny wizerunek. Główne cele programu to zacieśnianie więzi między rodzicami a dziećmi, integracja rodzin wielodzietnych, które dzięki specjalnie dostosowanej atrakcyjnej ofercie sportowo-kulturalno-edukacyjnej mogą wspólnie spędzać czas. Intencją programu jest także wzmacnianie i wspieranie kondycji finansowej wielodzietnych oraz zwiększanie szans rozwojowych i życiowych dzieci z tych rodzin.

Poniżej zamieszczono rysunek 2, który przedstawia tendencję zmian dotyczącą posiadania Gorzowskiej Karty Dużej Rodziny. 


\section{Rysunek 2. Gorzowska Karta Dużej Rodziny}

\section{Trend atrakcyjności karty}

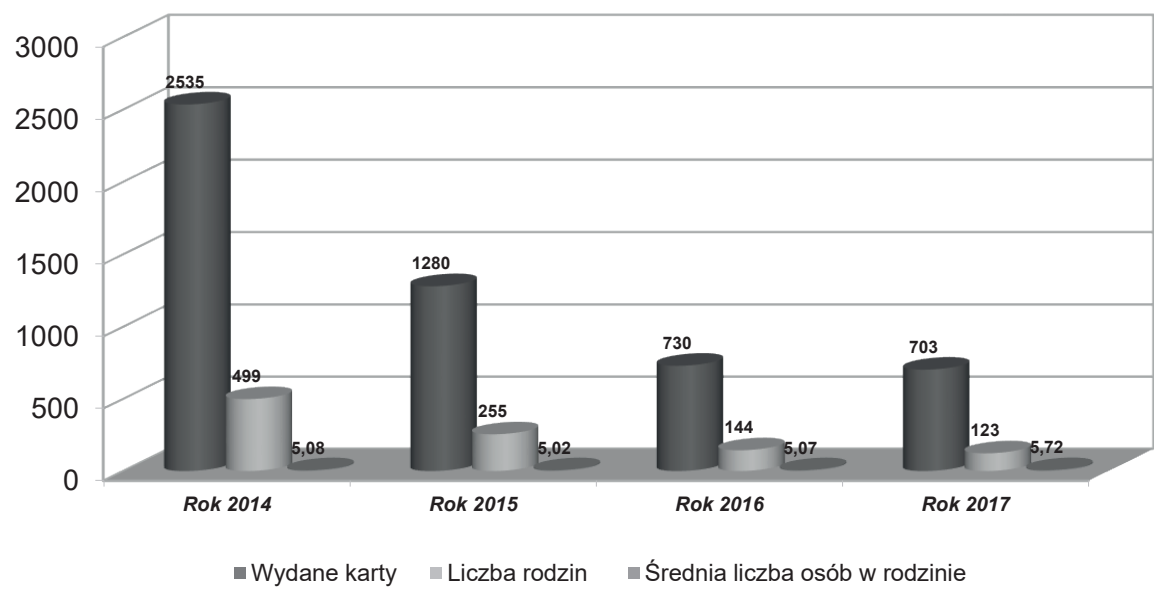

Źródło: opracowanie własne na podstawie danych pierwotnych z Wydziału Spraw Społecznych SOK, stanowisko nr 12.

Szczególnie dużym zainteresowaniem karta cieszyła się w czasie jej wprowadzania. W miarę upływu czasu następowało nasycenie rynku i obecnie sytuacja się ustabilizowała. Od początku funkcjonowania programu, czyli od połowy roku 2014 do 31 grudnia 2017 roku, przyznano karty 1021 rodzinom, czyli wydano 5248 kart dla uprawnionych posiadaczy z rodzin wielodzietnych.

\subsection{Gorzowska Karta Seniora}

Program Gorzowska Karta Seniora formalnie został przyjęty na sesji Rady Miejskiej Uchwałą Nr XXXV/419/2016 Rady Miasta Gorzowa Wlkp. z dnia 29 listopada 2016 r. w sprawie wprowadzenia na terenie Miasta Gorzowa Wlkp. Programu „Karta Seniora” oraz wydano Zarządzenie Nr 97/I/2017 Prezydenta Miasta Gorzowa Wlkp. z dnia 22 marca 2017 r. w sprawie ustalenia logo Programu „Karta Seniora” oraz Regulaminu przyznawania, wydawania i korzystania z „Karty Seniora”, które zmieniono Zarządzeniem Nr 118///2017 Prezydenta Miasta Gorzowa Wlkp. z dnia 6 kwietnia 2017. 
Rysunek 3. Gorzowska Karta Seniora

Trend atrakcyjności karty

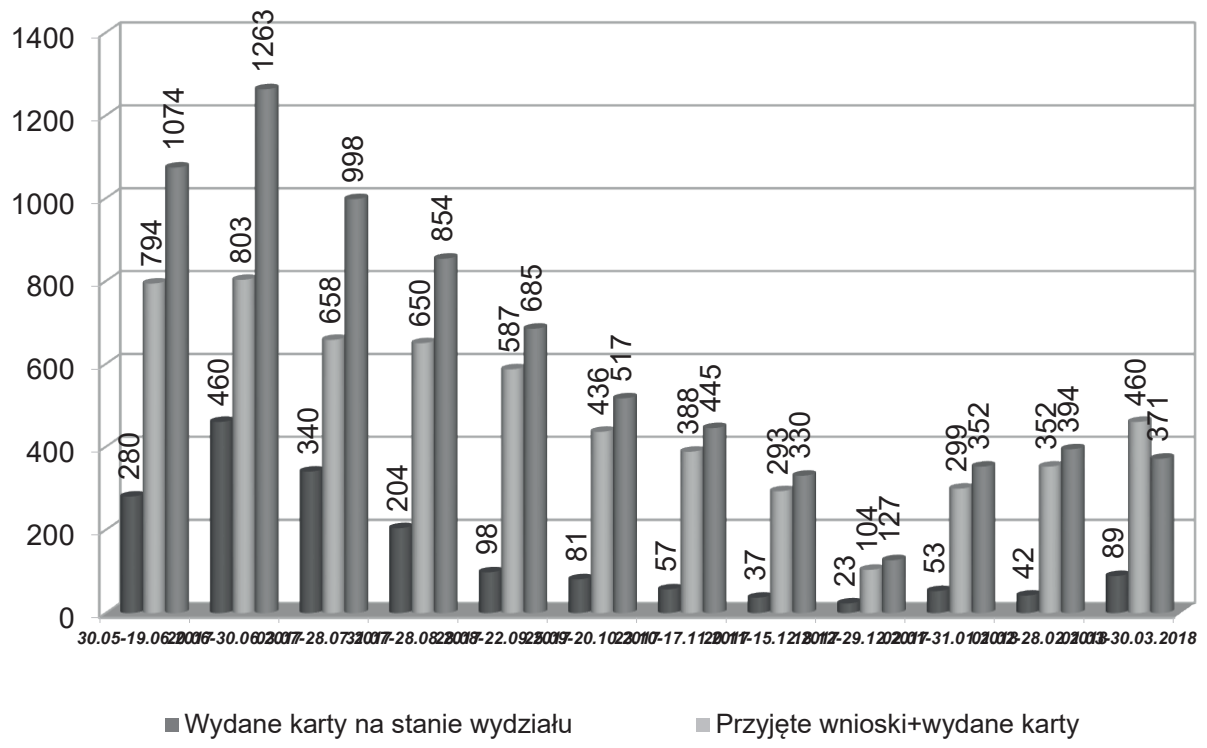

Źródło: opracowanie własne na podstawie danych pierwotnych z Wydziału Spraw Społecznych SOK, stanowisko nr 12.

Rysunek 3, przedstawiający trend atrakcyjności Karty Seniora, ukazuje, że zainteresowanie programem na samym początku było znaczne, co obserwowano w kilku etapach. Pierwszym był zalążek funkcjonowania programu, gdzie składano jedynie wnioski. Następną fazą wzrostową był okres, kiedy przeniesiono stanowisko ds. obsługi Karty Seniora do budynku głównego Urzędu Miasta. Ułatwiło to seniorom możliwość posiadania karty ze względu na położenie punktu obsługowego: śródmieście, blisko do środków komunikacji miejskiej. Trzecim momentem eskalacji zainteresowania kartą była możliwość posiadania karty od razu, to znaczy, dzięki zakupionym kartom oraz drukarce do personalizacji kart rozpoczęto wydawanie imiennych kart natychmiast po złożeniu wniosku. Po nasyceniu się rynku nastąpiła stabilizacja w wydawaniu Kart Seniora.

Zmiany demograficzne charakteryzujące się wzrostem liczebności osób po 60 . roku życia sprawiły, iż władze rządowe i samorządy lokalne musiały zintensyfiko- 
wać swoje działania i wprowadzić skuteczne instrumenty, aby zadbać o potrzeby nestorów i poprawić życie osób w tym wieku. Problematyka osób w wieku 60+ jest złożonym zagadnieniem, na który składa się wiele aspektów, ponieważ seniorzy w tym przedziale wiekowym są w różnym stanie zdrowia i wykazują różną aktywność społeczno-zawodową.

\section{Podsumowanie}

Niepokojące sygnały wynikające z Głównego Urzędu Statystycznego na temat profilu demograficznego społeczeństwa Polski zrodziły konieczność skoordynowania przedsięwzięć wszystkich instytucji i podmiotów oraz włączenie się samorządu terytorialnego organizacji pozarządowych do działań, mających na celu zniwelowanie problemów dotykających seniorów i rodzin wielodzietnych. $\mathrm{Z}$ tego powodu objęcie szczególną troską obu grup społecznych przez władze rządowe i samorządowe wydaje się optymalnym rozwiązaniem. $Z$ uwagi na proces starzenia się społeczeństwa pojawia się wiele problemów do rozwiązania, na przykład aktywizacja seniorów, którzy jeszcze są w pełni sprawni i chętnie uczestniczą w życiu społeczno-politycznym i ekonomicznym kraju czy miasta, opieka geriatryczna przy problemach zdrowotnych, domy pobytu dziennego dla zminimalizowania samotności, domy pobytu stałego w przypadku braku możliwości do samodzielnej egzystencji.

Ponadto zaufanie społeczne do administracji publicznej jest osłabione, gdyż w przeszłości utarł się stereotyp urzędu nieprzyjaznego, charakteryzującego się opieszałością w prowadzeniu spraw. Obecnie to klient/interesant jest w centrum uwagi i to od niego zależy, czy urząd uzyska miano przyjaznego i otwartego, i dlatego władze w administracji samorządowej muszą sprawnie reagować na potrzeby społeczności lokalnej, aby można było świadczyć usługi szybciej i lepszej jakości.

Występowanie dwóch programów prorodzinnych (Ogólnopolska Karta Dużej Rodziny i Gorzowska Karta Dużej Rodziny) w jednym mieście stało się idealnym rozwiązaniem dla miasta, gdyż one nie są dla siebie konkurencją, lecz synergią wzmacniającą oddziaływanie pomocowe dla rodzin wielodzietnych na lokalnym rynku. $\mathrm{Z}$ wypowiedzi rodziców wielodzietnych wynika (potwierdzają to również zestawienia statystyczne), że większość z nich ceni sobie możliwość korzystania z programu rządowego (Ogólnopolskiej Karty Dużej Rodziny) w Gorzowie Wielko- 
polskim, który jest uzupełnieniem niszy rynkowej, a funkcjonowanie obu programów jednocześnie sprzyja wypełnieniu tej luki.

\section{Bibliografia}

Bugdol, M. (2008). Zarządzanie jakościa w urzędach administracji publicznej - teoria i praktyka. Warszawa: Difin.

Kancelaria Prezesa Rady Ministrów (2008). Zarzadzanie satysfakcją klienta. Europejski poradnik praktyka. Warszawa.

Kancelaria Prezesa Rady Ministrów. (2012a). Projekt „,Klient w centrum uwagi administracji”. Wytyczne do wzmocnienia potencjatu administracji rzadowej. POKL w latach 2010-2012. Warszawa.

Kancelaria Prezesa Rady Ministrów (2012b). Wytyczne do wdrożenia standardów zarządzania satysfakcja klienta $w$ urzędach administracji rządowej. Pobrane z: https://dsc.kprm. gov.pl/sites/default/files/pliki/monitorowanie_wytyczne.pdf (20.11.2018).

Kancelaria Prezesa Rady Ministrów (2017a). Monitorowanie jakości obstugi klienta. Pobrane z: https://dsc.kprm.gov.pl/monitorowanie-jakosci-obslugi-klienta-1 (20.11.2018).

Kancelaria Prezesa Rady Ministrów (2017b). Pomiar jako środek do doskonalenia. Poprawa funkcjonowania sektora publicznego dzięki wykorzystaniu informacji na temat poziomu satysfakcji klienta-obywatel. Pobrane z: https://dsc.kprm.gov.pl/sites/default/files/ pliki/pomiar_jako_srodek_do_doskonalenia_2.pdf (20.11.2018).

Konstytucja (1997). Konstytucja RP z dnia 2 kwietnia 1997 r. Pobrane z: http://www.sejm. gov.pl/prawo/konst/polski/kon1.htm (dostęp: 20.11.2018).

Koszałka, J. (2011). Monitoring zapotrzebowania na ustugi i kształtowanie oferty ośrodka innowacji (s. 43-45). Warszawa: Polska Agencja Rozwoju Przedsiębiorczości.

Nawojczyk, M. (2015). Nowoczesne formy zarządzania w administracji publicznej. Zeszyty Naukowe Wyższej Szkoły Humanitas. Zarządzanie, 2, 169-181. DOI: $0.5604 / 18998658.1154748$.

MRPiPS (2018). Ministerstwo Rodziny, Pracy i Polityki Społecznej. Karta Dużej Rodziny. Pobrane z: https://www.mpips.gov.pl/wsparcie-dla-rodzin-z-dziecmi/karta-duzej-rodziny/ (20.11.2018).

Nieżurawski, L., Witkowska, J. (2007). Pojęcie satysfakcji klienta. Problemy Jakości, 39 (7), 31-35.

Osiadacz, J. (2012). Innowacje w sektorze ustug - przewodnik po systematyce oraz przykłady dobrych praktyk. Załącznik 3. Wrocław: Polska Agencja Rozwoju Przedsiębiorczości. 
Rozporządzenie (2017a). Rozporządzenie zmieniające Ministra Rodziny, Pracy i Polityki Społecznej z dnia 28 grudnia 2017 r. w sprawie sposobu unieważnienia Karty Dużej Rodziny, wzorów graficznych oraz szczegółowego zakresu informacji, jakie mają być zawarte we wniosku o przyznanie Karty Dużej Rodziny. Dz.U. z 2017, poz. 2449.

Rozporządzenie (2017b). Rozporządzenie Ministra Rodziny, Pracy i Polityki Społecznej z dnia 27 lipca 2017 r. w sprawie sposobu unieważnienia Karty Dużej Rodziny, wzorów graficznych oraz szczegółowego zakresu informacji, jakie mają być zawarte we wniosku o przyznanie Karty Dużej Rodziny. Dz.U. z 2017, poz. 1454.

Rutkowska, V. (2018). Sprawozdanie z realizacji Programu „Karta Dużej Rodziny” Uchwała Nr LII/598/2017 Rady Miasta Gorzowa Wielkopolskiego z dnia 27 września 2017 r. zmieniona Uchwałą Nr LVIII/725/2018 Rady Miasta Gorzowa Wielkopolskiego z dnia 31 stycznia 2018 r. za rok 2017.

Serafin, K. (2013). Skuteczna komunikacja w podmiotach administracji publicznej. Studia Ekonomiczne. Zeszyty Naukowe Uniwersytetu Ekonomicznego w Katowicach, 141, $136-151$.

Ustawa (2014). Ustawa z dnia 5 grudnia 2014 r. o Karcie Dużej Rodziny. Dz.U. z 2017, poz.1832 t.j.

Ustawa (2017). Ustawa z dnia 13 października 2017 r. o finansach publicznych. Dz.U. z 2017, poz. 2077 t.j.

\title{
CUSTOMER VALUE MANAGEMENT IN LOCAL GOVERNMENT
}

\begin{abstract}
The demographic survey shows that European societies are characterised by low fertility rates and continuing increases in longevity for the population aged 60 years or over. Therefore the state and local governments are beginning to develop special programmes which are targeted to specific social groups to improve quality of life. The issue relates to senior citizens who are people aged 60 years or over as well as large families with three or more children. The degree of the difficulty of the task to be carried out is significant. On the one hand, a local government needs to strengthen its position by improvement of the quality of services provided. While in the stereotype of residents' mentality an office does not have a positive image. Whilst on the other hand, contemporary clients are more demanding than they were a few years ago. The increase of client awareness among local people requires the
\end{abstract}


application of a result-oriented specified local policy. Combining these two options would be difficult, but achievable. There have existed certain projects prepared by the state government administrative organs aiming to introduce client service standards in public administration institutions. This process has already been launched. Work is also underway to create new models on the basis of the surveys conducted in communes where client service standards have been already implemented. There is considerable progress in public administration institutions, which is inevitable and will evolve if public administration is to become modern and to understand its clients' needs.

Translated by Katarzyna Demidowicz

Keywords: client/petitioner, public administration management, transformations of government offices

Kody JEL: R1, R5 